\title{
Impaired Voltage Gated Potassium Channel Responses in a Fetal Lamb Model of Persistent Pulmonary Hypertension of the Newborn
}

\author{
GIRIJA G. KONDURI, IVANE BAKHUTASHVILI, ANNIE EIS, AND KATHRYN M. GAUTHIER
}

\begin{abstract}
Departments of Pediatrics [G.G.K., I.B., A.E.], Pharmacology and Toxicology [K.M.G.], and Cardiovascular Research Center [G.G.K., I.B., A.E., K.M.G.], Medical College of Wisconsin and Zablocki VA Medical Center, Milwaukee, Wisconsin 53226
\end{abstract}

\begin{abstract}
We investigated the hypothesis that oxidative stress in persistent pulmonary hypertension of the newborn (PPHN) impairs voltage gated potassium $\left(\mathrm{K}_{\mathrm{v}}\right)$ channel function. We induced PPHN in fetal lambs by prenatal ligation of ductus arteriosus; controls had sham ligation. We studied changes in the tone of pulmonary artery (PA) rings and $\mathrm{K}_{\mathrm{v}}$ channel current of freshly isolated PA smooth muscle cells (PASMC) using standard techniques. 4-Aminopyridine (4-AP), a $\mathrm{K}_{\mathrm{v}}$ channel antagonist, induced dose-dependent constriction of control PA rings; this response was attenuated in PPHN pulmonary arteries. Exogenous superoxide and peroxynitrite inhibited the response to 4-AP in control rings. Tiron, a superoxide scavenger, improved the response to 4-AP in PPHN rings. 4-AP inhibited the NOS-independent relaxation response to ATP in control PA rings. Relaxation response to ATP was blunted in PPHN rings and was improved by NOS antagonist, $N$-nitro- L-arginine methyl ester (L-NAME). 4-AP attenuated this response in L-NAME-treated PPHN rings. Exogenous superoxide suppressed 4-AP sensitive $K_{v}$ current in control PASMC. $\mathrm{K}_{\mathrm{v}}$ channel current was attenuated in cells from PPHN lambs and was restored by tiron. Oxidative stress impairs $\mathrm{K}_{\mathrm{v}}$ channel function in PPHN. Superoxide scavengers may improve pulmonary vasodilation in PPHN in part by restoring $\mathrm{K}_{\mathrm{v}}$ channel function. (Pediatr Res 66: 289-294, 2009)
\end{abstract}

A TP is a purine nucleotide that contributes to the birth-related pulmonary vasodilation in fetal lambs (1-3). ATP causes vasodilation both by stimulation of $\mathrm{NO}$ release $(4,5)$ and by NO-independent mechanisms (4-6). Persistent pulmonary hypertension of the newborn (PPHN) occurs when pulmonary vascular resistance fails to decrease at birth. Studies in fetal lambs with PPHN induced by prenatal constriction of ductus arteriosus demonstrated impaired nitric oxide-cGMP-mediated vasodilation and an increase in oxidative stress in the pulmonary arteries (7-9). Increased superoxide $\left(\mathrm{O}_{2}{ }^{-}\right)$formation comes from a number of sources including NADPH oxidase (9) and uncoupled nitric oxide synthase (10) in this model of PPHN. $\mathrm{O}_{2}{ }^{--}$impairs vasodilation in part by reducing the availability of NO. The reaction of $\mathrm{O}_{2}^{--}$with $\mathrm{NO}$ results in the formation of peroxynitrite (11), which also contributes to impaired vasodilator responses. Scavenging $\mathrm{O}_{2}^{--}$with superoxide dismutase (SOD) or SOD mimic, tiron improves vasodilator response in PPHN $(12,10)$.

Received November 24, 2008; accepted May 7, 2009

Correspondence: Girija Ganesh Konduri, MD, Neonatology, Ste C410, CCC, 999, N 92nd St, Wauwatosa, WI 53226; e-mail: gkonduri@mcw.edu

Supported by RO1 HL 57268 from NHLBI and a grant-in-aid from American Heart Association Greater Midwest affiliate.
Vascular smooth muscle cell (VSMC) $\mathrm{K}^{+}$channels mediate both NO-dependent and NO-independent vasodilator responses in a number of vascular beds including pulmonary arteries. Potential NO-independent agonists for smooth muscle $\mathrm{K}^{+}$channels include endothelium-derived hyperpolarizing factors-either hydrogen peroxide $\left(\mathrm{H}_{2} \mathrm{O}_{2}\right)$ or metabolites of cytochrome P450 pathway $(13,14)$ and ATP $(6)$. Among the $\mathrm{K}^{+}$channels, voltage gated potassium channels $\left(\mathrm{K}_{\mathrm{v}}\right)$ and high conductance $\mathrm{Ca}^{2+}$ activated channels $\left(\mathrm{BK}_{\mathrm{Ca}}\right)$ contribute the majority of $\mathrm{K}^{+}$current (15). Developmental studies identified a maturational increase in $\mathrm{K}_{\mathrm{v}}$ channel expression and activity during fetal to neonatal transition (16). Previous studies in VSMC from the ductal ligation model of PPHN demonstrated that a decrease in $\mathrm{K}_{\mathrm{Ca}}$ channel activity and expression occur in PPHN (17). In contrast, the role of altered $\mathrm{K}_{\mathrm{v}}$ channel responses in PPHN and specifically the role of oxidative stress in impairing the $\mathrm{K}_{\mathrm{v}}$ channel responses are unknown. Oxidative stress from exposure to high glucose or pulmonary hypertension was shown to impair vasodilation by decrease in $\mathrm{K}_{\mathrm{v}}$ channel function in adult animal models and adult patients $(18-20)$. We investigated the hypothesis that oxidative stress impairs $\mathrm{K}_{\mathrm{v}}$ channel function and NO-independent vasodilator responses to ATP in PPHN induced by prenatal ductal constriction. We used isolated pulmonary artery (PA) rings and whole cell patch clamp of pulmonary VSMC from fetal lambs that underwent prenatal ductal constriction and control fetal lambs that had sham ligation of ductus arteriosus. The objectives of our studies are to investigate the functional responses of $\mathrm{K}_{\mathrm{v}}$ channels in pulmonary arteries and $\mathrm{K}_{\mathrm{v}}$ channel current of VSMC in control and PPHN lambs to identify the specific contribution of $\mathrm{O}_{2}^{--}$in the impaired vasodilation.

\section{MATERIALS AND METHODS}

Creation of PPHN model. Pregnant ewes were obtained at $118 \pm 2 \mathrm{~d}$ of gestation. After a period of acclimation, ewes underwent midline laparotomy and hysterotomy under general anesthesia at $128 \pm 2 \mathrm{~d}$ gestation. Fetal chest was exteriorized and a left lateral thoracotomy was done for ligation of ductus arteriosus (10). In control lambs, ductus arteriosus was exposed

Abbreviations: $\mathbf{K}_{\mathbf{v}}$ channel, voltage gated potassium channel; $\mathbf{B K}_{\mathbf{C a}}$, high conductance $\mathrm{Ca}^{2+}$ activated channels; GAPDH, glyceraldehyde 3 phosphate dehydrogenase; $\mathbf{H}_{2} \mathrm{O}_{2}$, hydrogen peroxide; $\mathbf{O}_{2}^{--}$, superoxide; PPHN, persistent pulmonary hypertension of newborn; SOD, superoxide dismutase; VSMC, vascular smooth muscle cell 
but not ligated. The ductal constriction was maintained for $8 \mathrm{~d}(128 \pm 2$ to $136 \pm 2$ d). Fetal lambs were delivered by $\mathrm{C}$-section, euthanized with an overdose of pentobarbital, and then lungs were harvested. Third to fifth generation pulmonary arteries were dissected for vascular ring studies (10) and fifth to seventh generation arteries for isolation of VSMC. The use of animals in the research protocol was approved by the Institutional Animal Care and Use Committee of Zablocki VA Medical Center and Medical College of Wisconsin.

Pulmonary artery ring studies. Third-fifth generation intrapulmonary arteries with an internal diameter of $300-500 \mu \mathrm{M}$ were dissected and isolated from the lung(10). The arteries were cut into rings $1 \mathrm{~mm}$ in length, suspended with stainless steel hooks in water-jacketed chambers, and connected to force displacement transducers (FTO3, Grass Instruments). The artery rings were bathed in $2 \mathrm{~mL}$ of physiologic salt solution kept at $37^{\circ} \mathrm{C}$ and aerated to maintain normal acid-base status and oxygenation of tissue. They were allowed to equilibrate for $45 \mathrm{~min}$ and stretched to a passive tension of $0.8 \mathrm{Gm}$. Investigation of the effects of 4-aminopyridine (4-AP) on basal tone was done without preconstriction of the rings. After equilibration and observing stable ring tension, 4-AP was added in concentrations of $10^{-5}-10^{-2} \mathrm{M}$. Ring tension was measured $10 \mathrm{~min}$ after the addition of each dose. In some experiments, PA rings from control lambs were preincubated with xanthine $\left(10^{-4} \mathrm{M}\right)+$ xanthine oxidase $(10 \mathrm{mU} / \mathrm{mL})$ or $5 \times 10^{-5} \mathrm{M}$ menadione $(21,22)$ to increase $\mathrm{O}_{2}^{--}$levels in the vessels or $10^{-4} \mathrm{M}$ peroxynitrite to provide nitrosative stress or $10^{-4} \mathrm{M}$ tiron to scavenge $\mathrm{O}_{2}^{--}$before the addition of 4 -AP. In other experiments, PA rings from PPHN lambs were incubated with the same agents before the addition of 4-AP. Evaluation of the relaxation response to ATP was done in rings preconstricted with $10^{-6}-10^{-7} \mathrm{M}$ norepinephrine. This dose of norpepinephrine gave stable constriction that reached $50 \%$ of maximal tension observed with $100 \mathrm{mM} \mathrm{KCl}$. The tension reached with norepinephrine constriction for each ring was normalized to $100 \%$ and the percent change from this tension with each dose of ATP was calculated. Relaxation responses to $10^{-8}-10^{-3} \mathrm{M}$ doses of ATP were determined. Separate rings were pretreated with $10^{-4} \mathrm{M}$ concentrations of $N$-nitro-L-arginine methyl ester (L-NAME), a nitric oxide synthase inhibitor, alone or with $10^{-3} \mathrm{M} 4-\mathrm{AP}$ followed by incremental exposure to ATP. In some studies, control rings were treated with a combination of L-NAME and $\mathrm{K}_{\mathrm{Ca}}$ channel antagonist, iberiotoxin $\left(10^{-7} \mathrm{M}\right)$ or $\mathrm{K}_{\mathrm{ATP}}$ channel antagonist, glybenclamide $\left(10^{-5} \mathrm{M}\right)$ followed by determination of the relaxation response to ATP.

Expression of $K_{v} 1.5$ channel protein in pulmonary arteries. Fifth to seventh generation pulmonary arteries were dissected clear of surrounding parenchyma, flash frozen in liquid nitrogen, pulverized, and placed in modified RIPA buffer (10). The mixture was homogenized, sonicated to break the cells and insoluble debris was removed by centrifugation. Protein concentration was measured and an aliquot $(15 \mu \mathrm{g})$ of the protein was used for immunoblotting with $\mathrm{K}_{\mathrm{v}} 1.5$ channel protein antibody and with antibody for glyceraldehyde 3 phosphate dehydrogenase (GAPDH), used as internal loading control. Autoradiograms were imaged with Adobe PhotoShop v5.5 software, and the relative band densities were quantified using NIH Image 1.62. Integrated OD for $\mathrm{K}_{\mathrm{v}} 1.5$ channel protein and GAPDH were measured and the ratios of $\mathrm{K}_{\mathrm{v}} 1.5 / \mathrm{GAPDH}$ were calculated for each sample.

Whole cell patch clamp of vascular smooth muscle for $K_{v}$ channels. Fifth to seventh generation pulmonary arteries were dissected clear of surrounding parenchyma and placed in ice-cold HBSS. VSMC were enzymatically dispersed from these arteries using published methods (23). Whole cell recordings of $\mathrm{K}^{+}$currents were obtained in freshly isolated PA smooth muscle cells by amphotericin-perforated patch clamp method using an amplifier (Axopatch 200B, Axon instruments) and pclamp 8 software (Axon instruments) as described previously (24). Macroscopic $\mathrm{K}^{+}$currents were generated by progressive $10-\mathrm{mv}$ depolarizing steps (500-ms duration, 5 -s intervals) from a constant holding potential of -60 to $+60 \mathrm{mV}$. Currents were sampled at 3 $\mathrm{kHz}$ and filtered at $1 \mathrm{kHz}$. After control currents were recorded, the $\mathrm{K}_{\mathrm{v}}$ channel blocker 4-AP was applied at $3 \mathrm{mM}$ concentration. In a single cell, $\mathrm{K}_{\mathrm{v}}$ current was defined as the difference between outward current recorded in drug-free bath solution and after superfusion with $3 \mathrm{mM}$ 4-AP (18). Trials were performed in triplicate and averaged to estimate peak current amplitudes (picoamperes per picofarad) to normalize for cellular membrane area. The membrane capacitance of each cell was estimated by integrating the capacitative current generated by a $10-\mathrm{mV}$ hyperpolarizing pulse after electronic cancellation of pipette-patch capacitance. In some experiments, smooth muscle cells from control PA were treated with xanthine $\left(10^{-4} \mathrm{M}\right)+$ xanthine oxidase $(10 \mathrm{mU} / \mathrm{mL})$ to generate $\mathrm{O}_{2}^{--}$and catalase $(500 \mathrm{U} / \mathrm{mL})$ to scavenge $\mathrm{H}_{2} \mathrm{O}_{2}$, a metabolite of $\mathrm{O}_{2}^{--}$(18). Control studies were done with addition of xanthine and catalase. Tiron $\left(10^{-4} \mathrm{M}\right)$, an $\mathrm{O}_{2}^{--}$scavenger was added to cells from PPHN pulmonary arteries to evaluate the effect of oxidative stress on $\mathrm{K}_{\mathrm{v}}$ current.

Drug preparation. All the chemicals used were obtained from Sigma Chemical Co. Chemical Co (St. Louis, MO). Antibody for $\mathrm{K}_{\mathrm{v}} 1.5$ channel was obtained from Alomone laboratories and the GAPDH antibody from Abcam, Cambridge, MA.

Statistical analysis. Data are shown as mean \pm 1 SD. Changes in vascular ring tension with incremental doses of 4-AP or ATP \pm different blockers were analyzed by two-way ANOVA. When a significant difference $(p<0.05)$ was found, a Duncan's multiple range test was done to determine which means were different. Comparison of densitometric data for $\mathrm{K}_{\mathrm{v}} 1.5$ channel protein from control and pulmonary hypertension groups was done by unpaired $t$ test.

\section{RESULTS}

Response of pulmonary artery rings to 4-AP. PA rings from control animals had a vigorous constrictor response to incremental doses of 4-AP (Fig. 1A). Addition of xanthine + xanthine oxidase or menadione to generate $\mathrm{O}_{2}^{--}$resulted in attenuation of the constrictor response to 4-AP in control rings. Similarly, addition of peroxynitrite caused attenuation of the constrictor response to 4-AP in control rings (Fig. 1A). Addition of tiron, an $\mathrm{O}_{2}^{--}$scavenger did not alter the response of control rings to 4-AP (Fig. 1A). These results together suggest that $\mathrm{K}_{\mathrm{v}}$ channels are active and contribute to the resting tone in the fetal pulmonary arteries and that oxidative stress impairs this basal $\mathrm{K}_{\mathrm{v}}$ channel activity. The response to 4-AP is blunted in vascular rings from PPHN lambs, suggesting decreased basal $\mathrm{K}_{\mathrm{v}}$ channel activity in PPHN (Fig. 1B). Addition of xanthine + xanthine oxidase or menadione to generate $\mathrm{O}_{2}^{--}$or peroxynitrite to increase nitrosative stress did not cause additional attenuation of the response to 4-AP. The $\mathrm{O}_{2}^{--}$scavenger, tiron restored the constrictor response to 4-AP in PPHN rings (Fig. 1B).

Response of PA rings to ATP. Control PA rings showed a dose-dependent relaxation response to ATP (Fig. 2A). Response to ATP was partly attenuated by NOS inhibitor, L-NAME. The NO-independent response observed in L-NAME-treated control PA rings was attenuated by 4-AP (Fig. 2A). PA rings from PPHN lambs showed no relaxation response to ATP (Fig. 2B), as we reported previously (10). The NOS inhibitor, L-NAME improved the relaxation response to ATP in PPHN rings, as reported previously (10). 4-AP inhibited the relaxation response observed in L-NAME-
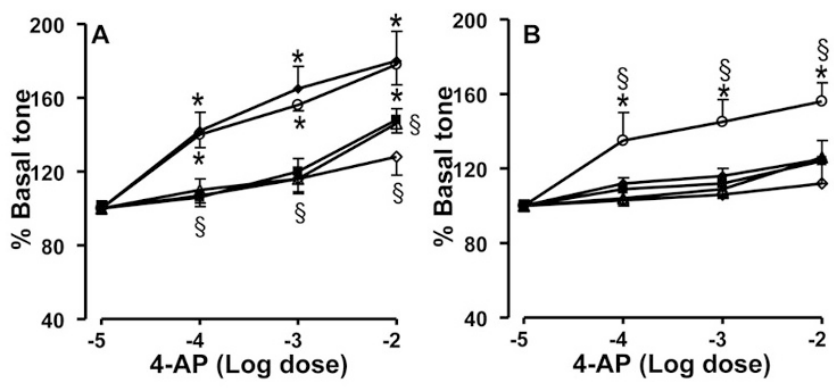

Figure 1. Effect of 4-AP on the basal tone of pulmonary artery rings from control $(A)$ and PPHN lambs $(B)$. Data are mean \pm SD for 15 rings from five animals each for 4-AP alone (- $\bullet$, tiron + 4-AP (-o-), xanthine + xanthine oxidase $+4-\mathrm{AP}(--)$, peroxynitrite $+4-\mathrm{AP}(-\Delta-)$, and menadione $+4-\mathrm{AP}(-\bullet-)$. *Indicates $p<0.05$ from $-5 \mathrm{M}$ concentration of 4-AP and §from 4-AP alone. The increase in basal tone in response to 4-AP in control rings was attenuated by xanthine + xanthine oxidase, menadione, and peroxynitrite $(A)$. The attenuated response to 4-AP in PPHN rings was improved by $\mathrm{O}_{2}^{--}$scavenger, tiron and not altered further by xanthine + xanthine oxidase, menadione, or peroxynitrite $(B)$. 

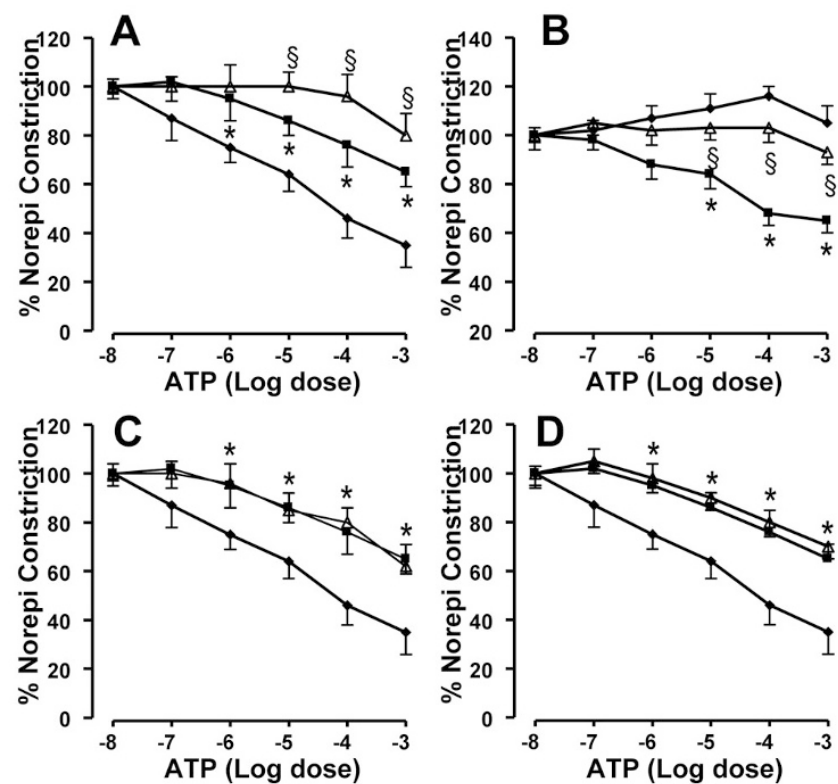

Figure 2. Effect of 4-AP on the NO-independent response to ATP in control $(A)$ and PPHN $(B)$ pulmonary artery rings. Data are mean \pm SD for 15 rings from five animals each for ATP alone (- -), L-NAME + ATP (--) and $\mathrm{L}-\mathrm{NAME}+4-\mathrm{AP}+\mathrm{ATP}(-\Delta-)$. *Indicates $p<0.05$ from ATP alone and $\S$ from L-NAME + ATP. The relaxation response to ATP in L-NAME-treated PA rings was attenuated by 4-AP in control and PPHN lambs $(A$ and $B)$. Effect of $\mathrm{K}_{\mathrm{Ca}}$ channel blocker iberiotoxin $(C)$ and $\mathrm{K}_{\mathrm{ATP}}$ channel blocker, glybenclamide $(D)$ on the relaxation response to ATP in L-NAME-treated control PA rings. Data are mean $\pm \mathrm{SD}$ for 12 rings from four animals each for ATP alone $(-\bullet-)$, L-NAME + ATP $(--)$ and L-NAME + iberiotoxin + ATP $(-\Delta-)$ in panel $C$ or L-NAME + glybenclamide + ATP $(-\Delta-)$ in panel $D$. *Indicates $p<0.05$ from ATP alone. Both iberiotoxin $\left(10^{-7} \mathrm{M}\right)$ and glybenclamide $\left(10^{-5} \mathrm{M}\right)$ failed to attenuate the NOS-independent relaxation response to ATP.

treated PPHN rings with ATP (Fig. $2 B$ ). The $\mathrm{K}_{\mathrm{Ca}}$ channel antagonist, iberiotoxin $\left(10^{-7} \mathrm{M}\right)$ and $\mathrm{K}_{\mathrm{ATP}}$ channel blocker, glybenclamide $\left(10^{-5} \mathrm{M}\right)$ did not alter the relaxation response of L-NAME-treated control PA rings to ATP (Fig. $2 C$ and $2 D$ ).

Expression of $K_{v} 1.5$ channel protein in PPHN. The protein levels of $\mathrm{K}_{\mathrm{v}} 1.5$ channel were not different between control and PPHN pulmonary arteries (Fig. 3). Although the ratio of $\mathrm{K}_{\mathrm{v}} 1.5$ to GAPDH seemed to be lower in PPHN group, the difference was not significant $(p=0.07$, Fig. 3$)$. These data are consistent with the report by Linden et al. (25) that $\mathrm{K}_{\mathrm{v}}$ 1.5 mRNA levels are not altered in PPHN. These data also support the functional studies in vascular rings and isolated smooth muscle cells that scavenging $\mathrm{O}_{2}^{--}$was effective in improving the $\mathrm{K}_{\mathrm{v}}$ channel responses.

Effect of $\mathrm{O}_{2}^{--}$and SOD mimetic on $K_{v}$ current. VSMC from control fetal pulmonary arteries showed $\mathrm{K}^{+}$current, which was inhibited by $3 \mathrm{mM}$ 4-AP (Fig. 4). Addition of xanthine + xanthine oxidase but not xanthine alone inhibited this $\mathrm{K}_{\mathrm{v}}$ current in control VSMC (Fig. 5). Further addition of 4-AP to VSMC in the presence of xanthine + xanthine oxidase had no effect on this current, indicating that $\mathrm{K}_{\mathrm{v}}$ current was already inhibited by $\mathrm{O}_{2}^{--}$(Fig. 5). Catalase was added to xanthine + xanthine oxidase to differentiate the effects of $\mathrm{O}_{2}{ }^{-}$ from its metabolite, $\mathrm{H}_{2} \mathrm{O}_{2} . \mathrm{K}^{+}$current of VSMC from PPHN lambs was not inhibited by 4-AP, indicating attenuation of $\mathrm{K}_{\mathrm{v}}$ current at basal level (Fig. 6) in PPHN. Addition of tiron
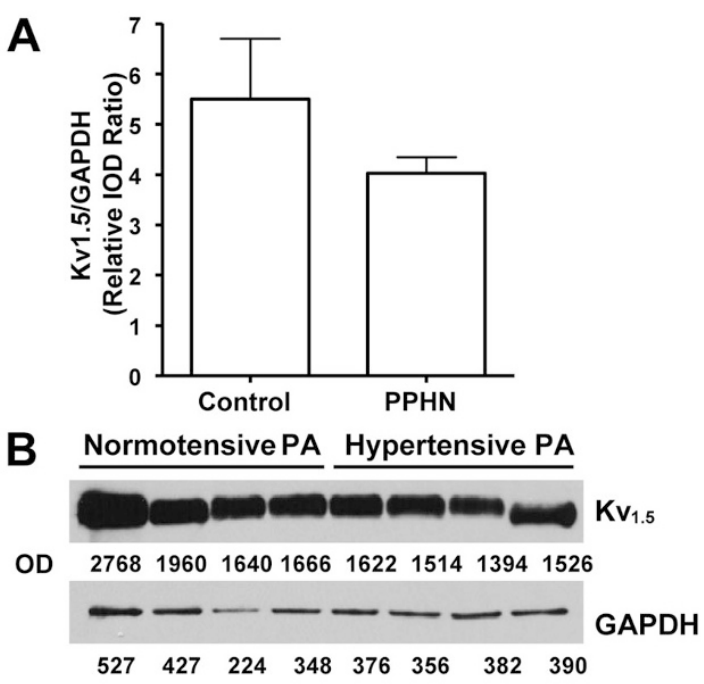

Figure 3. Summarized data $(A)$ and sample blot $(B)$ for $\mathrm{K}_{\mathrm{v}} 1.5$ channel protein levels assessed by immunoblotting with specific antibody. Summarized data from control and PPHN pulmonary artery homogenates are shown in $A$ as mean $\pm \mathrm{SD}$ of IOD ratios for $\mathrm{K}_{\mathrm{v}} 1.5$ channel protein and GAPDH, used as internal control. Sample blots from control and PPHN pulmonary arteries are shown in $B$. No significant difference $(p=0.07)$ was noted between control and PPHN groups $(A)$.

$\left(10^{-4} \mathrm{M}\right)$ restored the 4-AP sensitive $\mathrm{K}^{+}$current, indicating increase in $K_{v}$ current (Fig. 6). These data together suggest that oxidative stress in PPHN impairs $\mathrm{K}_{\mathrm{v}}$ channel function in VSMC.

\section{DISCUSSION}

Our study provides the evidence that $\mathrm{K}_{\mathrm{v}}$ channel function is impaired by oxidative stress in pulmonary arteries in PPHN. Because $\mathrm{K}_{\mathrm{v}}$ channels contribute to basal vascular tone and mediate the response of vascular smooth muscle to a number of vasodilators, their impaired function may result in an altered adaptation of pulmonary circulation at birth. Our study also provides evidence that scavenging $\mathrm{O}_{2}^{-}$restores the $\mathrm{K}_{\mathrm{v}}$ channel function in this model of PPHN.

Vascular $\mathrm{K}^{+}$channels play a major role in maintaining the basal tone and in the regulation of responses to vasoactive mediators. The $\mathrm{K}^{+}$channels are a heterogeneous group with different roles in mediating physiologic responses. The $\mathrm{K}_{\mathrm{v}}$ channels and $\mathrm{BK}_{\mathrm{Ca}}$ channels contribute the majority of resting $\mathrm{K}^{+}$current in VSMC (15). $\mathrm{BK}_{\mathrm{Ca}}$ channels regulate the capacitive $\mathrm{Ca}^{2+}$ entry and play an important role in the $\mathrm{O}_{2}$-induced pulmonary vasodilation in fetal lambs (26). These channels also undergo maturational changes during gestation (16). Olschewski et al. (17) demonstrated that the contribution of $\mathrm{K}_{\mathrm{Ca}}$ channel to membrane potential and $\mathrm{O}_{2}$ sensitivity are decreased in VSMC from lambs with PPHN induced by ductal ligation. However, alteration in the functional responses of $K_{v}$ channels in PPHN remains unclear. Previous studies in adult animals demonstrated that the $\mathrm{K}_{\mathrm{v}}$ channels, in particular $\mathrm{K}_{\mathrm{v}}$ 1.5 and $\mathrm{K}_{\mathrm{v}} 2.1$ play a significant role in the hypoxic pulmonary vasoconstriction (27). Hypoxia induced pulmonary hypertension in rats is associated with a decrease in $\mathrm{K}_{\mathrm{v}} 1.5$ channel protein (28). The distribution of $\mathrm{K}_{\mathrm{v}}$ channels also demon- 

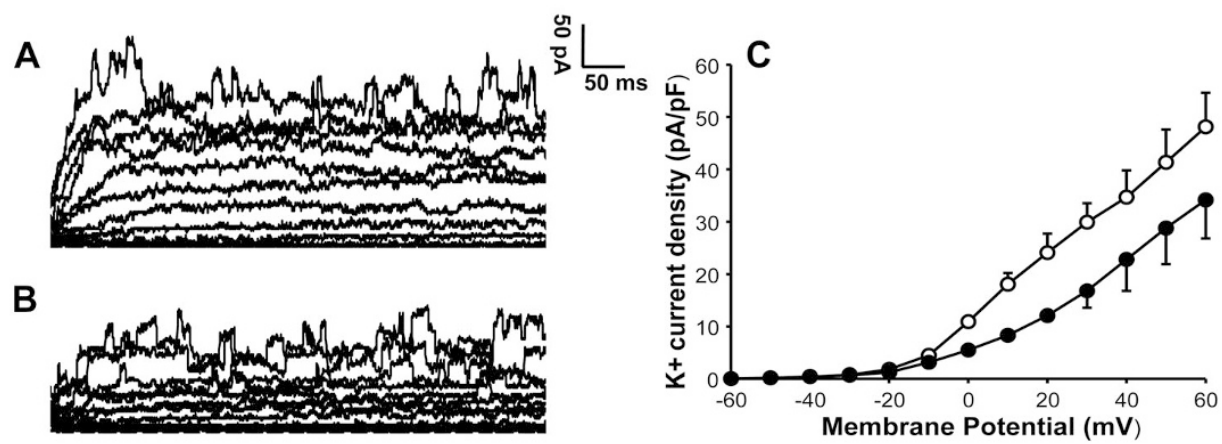

Figure 4. $\mathrm{K}^{+}$current of a pulmonary artery VSMC from a control lamb is shown at basal level $(A)$ and after application of 4-AP $(B)$. $\mathrm{K}^{+}$current shows significant suppression by $3 \mathrm{mM}$ 4-AP indicating the presence of $\mathrm{K}_{\mathrm{v}}$ channel activity in a control cell. Summarized data from four cells is shown to the right in panel $C$ for $\mathrm{K}^{+}$current density in the absence (-o-) or presence of 4-AP (-๑) and demonstrates inhibition of the current by 4-AP.

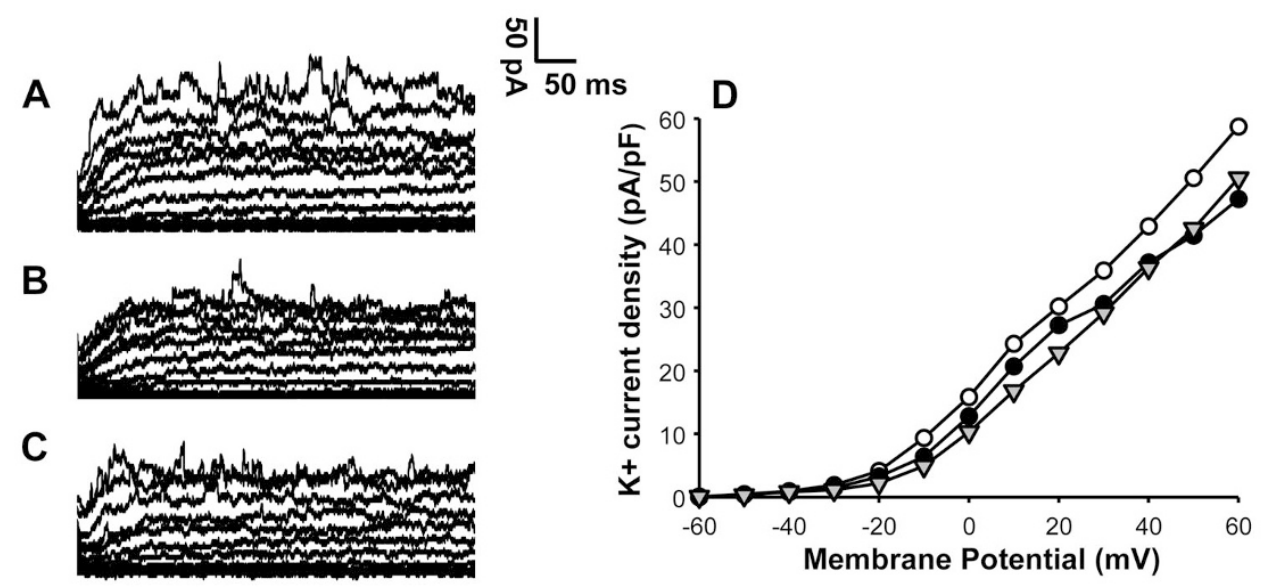

Figure 5. $\mathrm{K}^{+}$current from control PA VSMC in the presence of xanthine alone $(A)$, xanthine + xanthine oxidase to generate $\mathrm{O}_{2}^{--}(B)$ and xanthine + xanthine oxidase +4 -AP $(C)$. Xanthine alone $(A)$ did not alter the $\mathrm{K}^{+}$current. Addition of xanthine + xanthine oxidase resulted in suppression of $\mathrm{K}^{+}$current $(B)$. Further addition of 4-AP fails to alter $\mathrm{K}^{+}$current in the presence of xanthine + xanthine oxidase $(C)$, suggesting inhibition of $\mathrm{K}_{\mathrm{v}}$ current by $\mathrm{O}_{2}^{--}$. Summary data in panel $D$ show that xanthine + xanthine oxidase $(-\bullet-)$ attenuates the $\mathrm{K}^{+}$current density compared with xanthine alone $(-\circ-)$ and addition of 4 -AP to xanthine + xanthine oxidase (- $\Delta-)$ does not attenuate the $\mathrm{K}^{+}$current further.

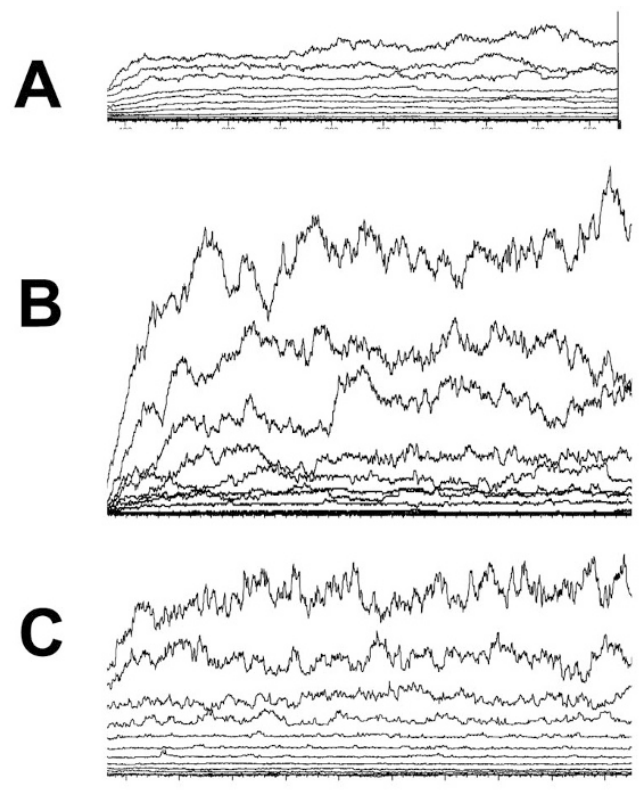

Basal
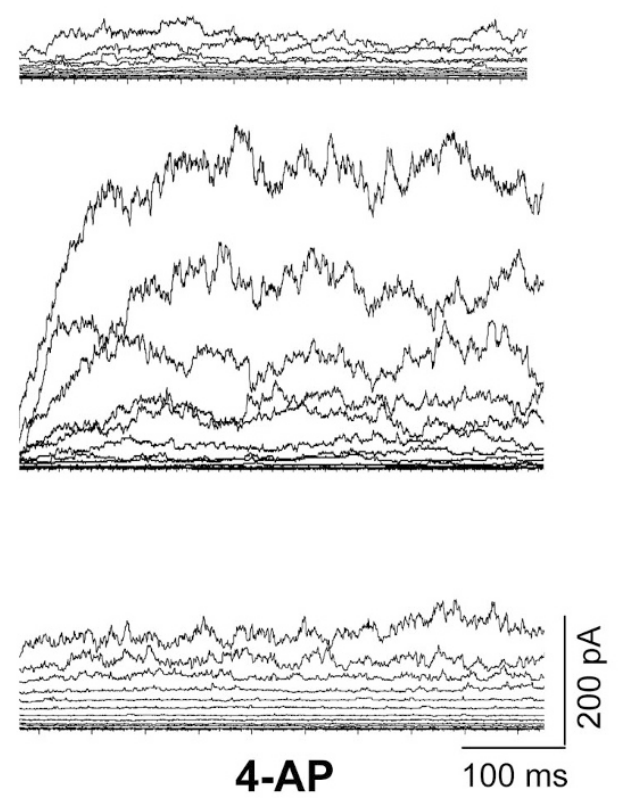

Figure 6. $\mathrm{K}^{+}$channel tracings of smooth muscle cells from control $(A)$ and PPHN $(B)$ cells and PPHN cells treated with tiron $(C)$. Suppression of $\mathrm{K}^{+}$current by $3 \mathrm{mM} 4-\mathrm{AP}$ was used to define $\mathrm{K}_{\mathrm{v}}$ channel current. The control smooth muscle cell $(A)$ shows $\mathrm{K}_{\mathrm{v}}$ channel current; this was attenuated in PPHN cell $(B)$. $\mathrm{O}_{2}{ }^{-}$ scavenger, tiron restores 4-AP sensitive current to PPHN smooth muscle cell $(C)$. 
strates a segmental heterogeneity with the distal resistance vessels showing predominance of $\mathrm{K}_{\mathrm{v}} 1.5$ channel protein (28). Gene therapy with $\mathrm{K}_{\mathrm{v}} 1.5$ channel protein ameliorates hypoxia induced pulmonary hypertension in rats (29). Based on the significance of resistance arteries in the regulation of pulmonary vascular tone and the role of $\mathrm{K}_{\mathrm{v}} 1.5$ channel in mediating pulmonary vasoconstriction, we investigated the alteration in this channel in the distal resistance vessels. We observed that the expression of this channel protein is not significantly altered in our model of PPHN induced by ductal ligation for $8 \mathrm{~d}$. Our results are similar to previous observation by Linden et al. (25) that the $\mathrm{K}_{\mathrm{v}}$ channel mRNA levels assessed by real time PCR are not altered in this model of PPHN. Whether longer exposure to pulmonary hypertension will result in decreased channel expression is unknown and requires further investigation. However, the function of $\mathrm{K}_{\mathrm{v}}$ channels in smooth muscle cells from resistance vessels is altered in PPHN.

Our study used ATP to test the relaxation response of pulmonary arteries because ATP causes both NO-mediated and NO-independent vasodilation (4-6). Our previous studies in rabbit pulmonary arteries showed that the relaxation response to ATP in L-NAME-treated and endothelium-denuded PA rings is independent of prostaglandin and cytochrome P450 pathways (6). Our new data suggest that the NOindependent response to ATP is mediated in part by $\mathrm{K}_{\mathrm{v}}$ channels and not by $\mathrm{K}_{\mathrm{Ca}}$ or $\mathrm{K}_{\mathrm{ATP}}$ channels. These data also support our previous observation in intact fetal lambs that glybenclamide, a $\mathrm{K}_{\mathrm{ATP}}$ channel antagonist, does not attenuate the vasodilator response to ATP (4).

Previous studies in adult animal models demonstrated that $\mathrm{K}_{\mathrm{v}}$ channel function is impaired by vascular oxidative stress induced by high glucose or pulmonary hypertension (18-20). Because oxidative stress impairs vasodilation in PPHN (910 ), we speculated that inhibition of $\mathrm{K}_{\mathrm{v}}$ channel function by $\mathrm{O}_{2}{ }^{--}$contributes to vascular dysfunction. We used xanthine + xanthine oxidase to generate $\mathrm{O}_{2}{ }^{--}$in our studies, as reported previously (19). Because xanthine + xanthine oxidase may generate variable levels of $\mathrm{O}_{2}{ }^{--}$based on enzyme activity in different preparations, we used menadione as an alternate source of $\mathrm{O}_{2}^{--}$to verify our results $(21,22)$. We observed that both oxidant generating systems caused similar attenuation of the response to 4-AP in PA rings. Our studies suggest that $\mathrm{O}_{2}{ }^{-}$impairs $\mathrm{K}_{\mathrm{v}}$ channel function in the fetal pulmonary arteries by inhibition of $\mathrm{K}_{\mathrm{v}}$ channel current. These observations are similar to the inhibitory effect of $\mathrm{O}_{2}{ }^{--}$on the rat coronary artery smooth muscle cells in response to high glucose (18). The mechanism by which $\mathrm{O}_{2}^{--}$induces $\mathrm{K}_{\mathrm{v}}$ channel dysfunction is not apparent from our studies. Although we used catalase in the studies done with xanthine + xanthine oxidase to remove $\mathrm{H}_{2} \mathrm{O}_{2}$ in control VSMC, the cell permeability of catalase in our preparation is uncertain. We did not use polyethylene glycol catalase, which has greater cell permeability. Therefore, we cannot exclude the contribution of intra-cellular $\mathrm{H}_{2} \mathrm{O}_{2}$ to the inhibition of $\mathrm{Kv}$ channel function in these studies. Nitration of $\mathrm{K}_{\mathrm{v}}$ channel protein was reported by other investigators in vascular dysfunction secondary to high glucose (30). Whether nitrosative stress con- tributes to impaired function of $\mathrm{K}_{\mathrm{v}}$ channels in PPHN requires further study.

Although an improvement in the relaxation response to ATP by inhibition of eNOS seems incongruous, our previous studies demonstrated that eNOS is uncoupled and becomes a source of $\mathrm{O}_{2}^{-}$in PPHN (10). The improved vasodilation observed in L-NAME-treated pulmonary arteries seems to be mediated in part by restoration of $\mathrm{K}_{\mathrm{v}}$ channel function, based on inhibition of this response by 4-AP in vascular rings. Whether the improvement in $\mathrm{K}_{\mathrm{v}}$ channel function by antioxidants restores response to other vasodilators requires further investigation. $\mathrm{O}_{2}^{--}$also seems to contribute to altered $\mathrm{K}_{\mathrm{v}}$ channel function in isolated VSMC from PPHN lambs; however, the source of this $\mathrm{O}_{2}^{--}$in VSMC is not clear from our studies. NADPH oxidase and mitochondria are important sources of $\mathrm{O}_{2}^{--}$in vascular cells (31) and their contribution to impaired $\mathrm{KV}$ channel activity in VSMC in PPHN requires further investigation.

The significance of our observations is that the impaired $\mathrm{K}_{\mathrm{v}}$ channel function was improved by a scavenger of $\mathrm{O}_{2}^{--}$, tiron. Recombinant human SOD has been shown to improve pulmonary vasodilation and oxygenation in fetal lambs with PPHN (12,32). An improvement in the response to exogenous NO was also noted in this model after the treatment with SOD $(12,32)$. Our previous in vitro studies on pulmonary arteries isolated from PPHN lambs demonstrated that scavenging $\mathrm{O}_{2}{ }^{-}$ by tiron or inhibition of uncoupled eNOS by L-NAME improves the relaxation response to ATP (10). Our present study demonstrated that the $\mathrm{O}_{2}^{-}{ }^{-}$scavenger, tiron restores the $\mathrm{K}_{\mathrm{v}}$ channel current in VSMC from PPHN pulmonary arteries. Whether $\mathrm{O}_{2}^{--}$scavengers will have a role in the treatment of PPHN requires further investigation in the animal models and in babies with PPHN.

\section{REFERENCES}

1. Konduri GG, Gervasio CT, Theodorou AA 1993 Role of adenosine triphosphate and adenosine in oxygen induced pulmonary vasodilation in fetal lambs. Pediatr Res 33:533-539

2. Konduri GG, Mattei J 2002 Role of oxidative phosphorylation and ATP release in birth related pulmonary vasodilation in fetal lambs. Am J Physiol Heart Circ Physiol 283:H1600-H1608

3. Konduri GG, Mital S, Gervasio CT, Rotta AT, Forman K 1997 Purine nucleotides contribute to pulmonary vasodilation caused by birth related stimuli in the ovine fetus. Am J Physiol 272:H2377-H2384

4. Konduri GG, Mital S 2000 Adenosine and ATP cause nitric oxide-dependent pulmonary vasodilation in fetal lambs. Biol Neonate 78:220-229

5. Fineman JR, Heymann MA, Soifer SJ 1991 N omega-nitro-L-arginine attenuates endothelium-dependent pulmonary vasodilation in lambs. Am J Physiol 260:H1299-H1306

6. Konduri GG, Bakhutashvili I, Frenn R, Chandrasekhar I, Jacobs ER, Khanna AK 2004 P2Y purine receptor responses and expression in the pulmonary circulation of juvenile rabbits. Am J Physiol Heart Circ Physiol 287:H157-H164

7. Shaul PW, Yuhanna IS, German Z, Chen Z, Steinhorn RH, Morin FC 1997 Pulmonary endothelial NO synthase gene expression is decreased in fetal lambs with pulmonary hypertension. Am J Physiol 272:L1005-L1012

8. Steinhorn RH, Russell JA, Morin FC III 1995 Disruption of cGMP production in pulmonary arteries isolated from fetal lambs with pulmonary hypertension. Am J Physiol 268:H1483-H1489

9. Brennan LA, Steinhorn RH, Wedgwood S, Mata-Greenwood E, Roark EA, Russell JA, Black SM 2003 Increased superoxide generation is associated with pulmonary hypertension in fetal lambs: a role for NADPH oxidase. Circ Res 92:683-691

10. Konduri GG, Bakhutashvili I, Eis A, Pritchard K Jr 2007 Oxidant stress from uncoupled nitric oxide synthase impairs vasodilation in fetal lambs with persistent pulmonary hypertension. Am J Physiol Heart Circ Physiol 292:H1812-H1820

11. Beckman JS, Koppenol WH 1996 Nitric oxide, superoxide, and peroxynitrite: the good, the bad, and the ugly. Am J Physiol 271:C1424-C1437 
12. Steinhorn RH, Albert G, Swartz DD, Russell JA, Levine CR, Davis JM 2001 Recombinant human superoxide dismutase enhances the effect of inhaled nitric oxide in persistent pulmonary hypertension. Am J Respir Crit Care Med 164:834-839

13. Larsen BT, Miura H, Hatoum OA, Campbell WB, Hammock BD, Zeldin DC, Falck JR, Gutterman DD 2006 Epoxyeicosatrienoic and dihydroxyeicosatrienoic acids dilate human coronary arterioles via $\mathrm{BK}(\mathrm{Ca})$ channels: implications for soluble epoxide hydrolase inhibition. Am J Physiol Heart Circ Physiol 290:H491-H499

14. Miura H, Bosnjak JJ, Ning G, Saito T, Miura M, Gutterman DD 2003 Role for hydrogen peroxide in flow-induced dilation of human coronary arterioles. Circ Res 92:e31-e40

15. Leblanc N, Wan X, Leung PM 1994 Physiological role of $\mathrm{Ca}^{2+}$-activated and voltage-dependent $\mathrm{K}^{+}$currents in rabbit coronary myocytes. Am J Physiol 266: $\mathrm{C} 1523-\mathrm{C} 1537$

16. Cornfield DN, Saqueton CB, Porter VA, Herron J, Resnik E, Haddad IY, Reeve HL 2000 Voltage-gated $\mathrm{K}(+)$-channel activity in ovine pulmonary vasculature is developmentally regulated. Am J Physiol Lung Cell Mol Physiol 278:L1297-L1304

17. Olschewski A, Hong Z, Linden BC, Porter VA, Weir EK, Cornfield DN 2002 Contribution of the $\mathrm{K}(\mathrm{Ca})$ channel to membrane potential and $\mathrm{O} 2$ sensitivity is decreased in an ovine PPHN model. Am J Physiol Lung Cell Mol Physiol 283:L1103-L1109

18. Liu Y, Terata K, Rusch NJ, Gutterman DD 2001 High glucose impairs voltage-gated $\mathrm{K}(+)$ channel current in rat small coronary arteries. Circ Res 89:146-152

19. Bubolz AH, Li H, Wu Q, Liu Y 2005 Enhanced oxidative stress impairs cAMPmediated dilation by reducing $\mathrm{Kv}$ channel function in small coronary arteries of diabetic rats. Am J Physiol Heart Circ Physiol 289:H1873-H1880

20. Yuan JX, Aldinger AM, Juhaszova M, Wang J, Conte JV Jr, Gaine SP, Orens JB, Rubin LJ 1998 Dysfunctional voltage-gated $\mathrm{K}^{+}$channels in pulmonary artery smooth muscle cells of patients with primary pulmonary hypertension. Circulation 98:1400-1406

21. Criddle DN, Gillies S, Baumgartner-Wilson HK, Jaffar M, Chinje EC, Passmore S, Chvanov M, Barrow S, Gerasimenko OV, Tepikin AV, Sutton R, Petersen OH 2006 Menadione-induced reactive oxygen species generation via redox cycling promotes apoptosis of murine pancreatic acinar cells. J Biol Chem 281:40485-40492

22. Sampath V, Radish AC, Eis AL, Broniowska K, Hogg N, Konduri GG 2009 Attenuation of lipopolysaccharide-induced oxidative stress and apoptosis in fetal pulmonary artery endothelial cells by hypoxia. Free Radic Biol Med 46:663-671
23. Jackson WF, Huebner JM, Rusch NJ 1997 Enzymatic isolation and characterization of single vascular smooth muscle cells from cremasteric arterioles. Microcirculation $4: 35-40$

24. Gebremedhin D, Ma YH, Falck JR, Roman RJ, VanRollins M, Harder DR 1992 Mechanism of action of cerebral epoxyeicosatrienoic acids on cerebral arterial smooth muscle. Am J Physiol 263:H519-H525

25. Linden BC, Resnik ER, Hendrickson KJ, Herron JM, O'Connor TJ, Cornfield DN 2003 Chronic intrauterine pulmonary hypertension compromises fetal pulmonary artery smooth muscle cell O2 sensing. Am J Physiol Lung Cell Mol Physiol 285:L1354-L1361

26. Cornfield DN, Reeve HL, Tolarova S, Weir EK, Archer S 1996 Oxygen causes fetal pulmonary vasodilation through activation of a calcium-dependent potassium channel. Proc Natl Acad Sci USA 93:8089-8094

27. Archer SL, Souil E, Dinh-Xuan AT, Schremmer B, Mercier JC, El Yaagoubi A, Nguyen-Huu L, Reeve HL, Hampl V 1998 Molecular identification of the role of voltage-gated $\mathrm{K}^{+}$channels, Kv1.5 and Kv2.1, in hypoxic pulmonary vasoconstriction and control of resting membrane potential in rat pulmonary artery myocytes. J Clin Invest 101:2319-2330

28. Archer SL, Wu XC, Thébaud B, Nsair A, Bonnet S, Tyrrell B, McMurtry MS, Hashimoto K, Harry G, Michelakis ED 2004 Preferential Expression and Function of Voltage-Gated, O2-Sensitive $\mathrm{K}^{+}$Channels in Resistance Pulmonary Arteries explains Regional Heterogeneity in Hypoxic Pulmonary Vasoconstriction: Ionic Diversity in smooth Muscle Cells. Circ Res 95:308-318

29. Pozeg ZI, Michelakis ED, McMurtry MS, Thébaud B, Wu XC, Dyck JR, Hashimoto K, Wang S, Moudgil R, Harry G, Sultanian R, Koshal A, Archer SL 2003 In vivo gene transfer of the O2-sensitive potassium channel Kv1.5 reduces pulmonary hypertension and restores hypoxic pulmonary vasoconstriction in chronically hypoxic rats. Circulation 107:2037-2044

30. Li H, Gutterman DD, Rusch NJ, Bubolz A, Liu Y 2004 Nitration and functional loss of voltage-gated $\mathrm{K}^{+}$channels in rat coronary microvessels exposed to high glucose. Diabetes 53:2436-2442

31. Mueller CF, Laude K, McNally JS, Harrison DG 2005 Redox Mechanisms in Blood Vessels. Arterioscler Thromb Vasc Biol 25:274-278

32. Lakshminrusimha S, Russell JA, Wedgwood S, Gugino SF, Kazzaz JA, Davis JM, Steinhorn RH 2006 Superoxide dismutase improves oxygenation and reduces oxidation in neonatal pulmonary hypertension. Am J Respir Crit Care Med 174:13701377 